\title{
Methods of rapid appraisal for in-situ management of genetic resources: a Malagasy set of tools ${ }^{1}$
}

\author{
Didier BABIN ${ }^{\mathrm{a}, *}$, Fleurette AndriAntsilavo ${ }^{\mathrm{b}}$, Sigrid AUbert ${ }^{\mathrm{a}}$, \\ Géraldine PÉCHARD ${ }^{a}$, Caroline Bourgeois ${ }^{a}$, Martine Antona ${ }^{a}$, \\ Eléonore BÉCHAUX ${ }^{\mathrm{a}}$, Lolona RAMAMONJISOA RANAIVOSON ${ }^{\mathrm{c}}$, \\ Hélène I. JOLY ${ }^{\mathrm{a}}$
}

${ }^{\text {a }}$ Cirad, Campus international de Baillarguet, 34398 Montpellier, France

b Direction générale des Eaux et Forêts, BP 243, Nanisana, Antananarivo, Madagascar

${ }^{\mathrm{c}}$ Silo national des graines forestières, BP 5091, Ambatobe, Antananarivo, Madagascar

\begin{abstract}
The Convention on Biological Diversity confirms the sovereign rights of States over their biological resources. This implies duties of conservation and management. The tools placed at their disposal are often lacking, especially in developing countries with low technical and financial means. The work undertaken here, by a multidisciplinary Franco-Malagasy team, made it possible to give a diagnosis of the current conditions of in-situ management of two species exploited in Madagascar for their pharmaceutical interest: Prunus africanum and Centella asiatica. We developed tools for fast and indirect evaluation of the impact of the harvesting practices on the dynamics of the genetic diversity. A matrix was established to analyze the complexity of legal aspects. Economic features of commodities were surveyed. We showed that the management of populations of economically significant species is often alarming. Harvesting practices take little account of the risks incurred by a reduction in genetic diversity. The sharing of benefits arising from the exploitation of the genetic resources is far from equitable.
\end{abstract}

rapid appraisal / in-situ management / genetic resource / medicinal plant / toolbox

\footnotetext{
1 This paper is dedicated to the memory of Mamy Razafindrabe and Abdou-Salam Ouédraogo.

* Correspondence and reprints

E-mail: didier.babin@cirad.fr
} 
Résumé - Méthodes d'évaluation rapide pour la gestion in situ des ressources génétiques : l'exemple malgache. La Convention sur la Diversité Biologique confirme les droits souverains des États sur leurs ressources biologiques comme fondement de leur pouvoir à déterminer l'accès aux ressources génétiques de leur territoire. Cette souveraineté implique, du fait de la reconnaissance de la diversité biologique comme une préoccupation commune de l'humanité, des devoirs de conservation et de gestion. Mais les outils mis à leur disposition font souvent défaut, en particulier dans les pays en développement lorsque la gestio'ı doit se mettre en œuvre rapidement dans le cadre de projet de développement et avec des moyens techniques et financiers relativement réduits. La recherche-action entreprise ici par une équipe franco-malgache pluridisciplinaire, a permis de faire un état du dispositif réglementaire et un diagnostic des conditions actuelles de gestion in situ de deux espèces exploitées à Madagascar pour leur intérêt pharmaceutique : Prunus africanum et Centella asiatica. Nous avons développé des outils d'évaluations rapides et indirectes de l'impact des pratiques de cueillette sur la dynamique de la diversité génétique de ces espèces. Des études économiques ont permis d'identifier les acteurs et le fonctionnement des filières économiques. Enfin nous avons mis au point des grilles d'analyse de la faisabilité et de la concrétisation d'un partage des avantages plus conforme à la Convention sur la Diversité Biologique. Nous montrons que la gestion de populations d'espèces économiquement importantes et biologiquement sensibles est souvent alarmante ; les modes de gestion mis en œuvre prennent peu en compte les risques encourus par une réduction trop importante de la diversité génétique ; le partage juste et équitable des avantages découlant de l'exploitation des ressources génétiques est, pour l'heure, loin d'être réalisé. Une étude prospective a été réalisée pour évaluer les conditions de faisabilité d'arrangements contractuels relatifs à l'exploitation et la valorisation de la diversité génétique. Nous avons analysé les modalités d'accès aux ressources génétiques et de partage des avantages qui pouvaient être envisagées pour les deux espèces étudiées. Cependant, les solutions testées, à savoir le transfert de gestion des ressources phytogénétiques aux communautés locales, prévu dans les projets de réglementation d'une part et le recours à des contrats de transfert de technologie d'autre part, ne sont des atouts potentiels pour le développement économique de Madagascar que sous réserve du renforcement rapide des capacités locales et nationales pour instaurer les conditions d'une réelle conciliation des intérêts multiples entre les différentes parties prenantes de la gestion. En effet, l'intégration de la diversité des fonctions environnementales, sociales et économiques des ressources génétiques et des objectifs, souvent contradictoires, des acteurs suppose des choix préalables dans le cadre d'une réflexion d'ensemble d'un plan de gestion et d'aménagement. Et c'est seulement dans ce cadre que pourront s'exprimer les actions idoines, fondées sur les connaissances scientifiques, techniques et le savoir-faire local.

\section{évaluation rapide / gestion in-situ / ressource génétique / plante médicinale / boîte à outils}




\section{INTRODUCTION}

The management of $i n$-situ genetic resources*2 ${ }^{* 2}$ relies not only on biological data relating to a given species. Information about the dynamics of the ecosystem* is also necessary along with local or indigenous knowledge regarding the uses and the social and legal context within which the genetic diversity is managed. The Convention on Biological Diversity (CBD) aims at "the conservation of biological diversity*, the sustainable use ( $^{*}$ its components and the fair and equitable sharing of the benefits arising out of the utilization of genetic resources* ${ }^{*}$ including by appropriate access to genetic resources and by appropriate transfer of relevant technologies*, taking into account all rights over those resources and to technologies, and by appropriate funding." (1992).

The Convention needs an integrated approach including biology, law, economics and management in order to develop effective implementation tools. We have attempted to develop a global approach to assess projects on genetic resources management. It has been tested on exploited biological resources* and projects in Madagascar.

In Madagascar, the management of biological diversity is realized within the Environment Program and executed by non-governmental organizations (NGOs) or governmental agencies within the framework of a project. The fiveyear duration of these projects makes it difficult to estimate their effectiveness in terms of biological diversity. Within the project time cycle, human, technical and financial factors constrain this assessment. Therefore there is a need for methods and tools to carry out a rapid appraisal of in-situ management of genetic resources.

Our work has been built around three approaches mainly in the biological, legal, economic and organizational aspects of genetic resources management:

- the observation of the practices of exploitation of a biological resource allows one to carry out a diagnosis of the evolution of its genetic diversity;

- norms can be effective and pertinent social regulation tools when legal pluralism integrates all the legal domains concerning the in-situ management of the genetic resources;

- the economic structure and functioning of the biological resources industry can affect the way in which the benefits arising out of the utilization of the genetic resources are shared.

\section{MATERIALS AND METHODS}

The exploitation of a biological resource is not a synonym for its destruction or its disappearance. This is one of the assumptions made by the CBD. Natural resources are renewable so long as they are managed in a viable way.

${ }^{2}$ All the asterisked terms refer to the use of terms of the Convention on Biological Diversity (article 2). 
Management tools of renewable resource exploitation are well-known and have been studied [16], the exploitation of a renewable natural resource can affect the genetic resources because it modifies the $i n-s i t u$ conditions* and can reinforce or reduce natural processes of the evolution of genetic diversity.

\subsection{Programming support analysis}

We used available guidelines for forest sector development co-operation [12] to review the Malagasy situation in the sector of in-situ management of biological diversity and genetic resources. These guidelines were useful in appraising the various phases of the project cycle, from the identification of the objectives of the project to its feasibility, implementation and evaluation. We used these guidelines to assess the priority of support for genetic diversity management and to identify themes for support. The analysis was made during a workshop in 1998 which included Malagasy and French experts involved in the sector (a biologist, a geneticist, an economist, a jurist, a sociologist and a geographer) (3.1.). This workshop strengthened our ideas about undertaking a study of some exploited biological resources and current projects.

\subsection{Choice of species}

We chose two plant species (Prunus africana, Centella asiatica) of major interest for Madagascar. A wide search for information about $P$. africana and C. asiatica was initiated (scientific bibliography and unpublished literature, data bases, herbariums, Internet sites, direct contacts with people in the fields of exploitation...). The search concerned biological, legal and economic aspects (3.2.).

\subsection{The law: a dynamic complexity}

We developed a matrix in order to characterize the complex "bundle of rights" over biodiversity and natural renewable resources in Madagascar. We chose an anthropological and juridical approach. This approach highlights why the structural model of property schemes inherited from the French civil code tradition is not well suited to the analysis of modes of appropriations of biodiversity and genetic resources. The double dichotomy "thing / asset" (chose/bien) and "public / private" [15] is not adapted to the customs on which the social organization of Malagasy rural communities is generally based.

This matrix considered a twofold typology: firstly a typology of the various objects of rights over the resource, taken both in spatial and biological dimensions (from gene to biosphere); secondly a typology of the origin of the rights which have been claimed to exploit resources (process of anthropisation of nature, assignment of a function by a juridical order of references, social relations 
structuring). This matrix was applied in the rural district of Didy (East coast of Madagascar) in order to inventory all the rights and obligations claimed by the actors in natural and renewable resources management. It was completed by an analysis, using the theory of land tenure [15], to link appropriation modes with methods of management of renewable resources.

This approach allowed us to discuss some inconsistencies in the competition between legal and legitimate norms (3.3.). We were able to draw several scenarios of natural and renewable resources management in which juridical norms could be elaborated and be viable on both local and national scales (4.).

\subsection{Evaluation of the impact of harvesting practices on genetic diversity}

We have based our approach on the work carried out by Namkoong [17] on genetic criteria and indicators for sustainable forest management. Assumptions are made regarding the impact of various human actions on genetic processes such as drift, direct and indirect selection, mating system and gene flow. We have extended this approach to take into account the biology of the species harvested (3.4.).

\subsection{Evaluation of the conditions required to achieve benefit-sharing}

We studied the economic characteristics of the exploitation of $P$. africana and $C$. asiatica. Unlike the Rapid Rural Appraisal tools for a rural area, our approach focused on the whole industry from the harvesters to wholesalers involved in local trade or exports of raw materials or processed products. This study indicated the present state of benefit-sharing derived from resource exploitation. This benefit-sharing differs from that designed by the Convention on Biological Diversity, but nevertheless current efforts to adapt legal procedures make a more equitable benefit-sharing conceivable. Contracts can be proposed which design compensations that generate benefit-sharing in the access to and trade in genetic resources. The compensations cover a large range of agreements such as technology transfer or royalty payments. We propose here an analytical framework to study the feasibility and achievement of such contracts, based on the economic theory of incomplete contracts. We applied this framework to $P$. africana and $C$. asiatica in Madagascar. Two panels were constructed (Tab. I). The first one presents the main factors which influence feasibility independently of the direct will of parties to enter contracts. We focused on the features of the transaction defined by the contract and on the asymmetry of informational and technical capabilities between the contractors. We derived conditions of feasibility mixing ecological considerations such as scarcity or substitution and economic and social considerations such as market conditions or structure of 
the commodity system. The second panel focused on negotiating power between contractors in order to integrate the effects of interests and strategies of the considered parties. Information used for these analyses arises mostly from local investigations but also from bibliographic references. The method was applied to both resources ( $P$. africana and $C$. asiatica), but for illustration only (3.5.), using hypothetical scenarios.

\section{RESULTS}

\subsection{Assessing the priority of support for in-situ management of genetic resources}

The 1998 working study helped us to analyze the main strengths and weaknesses of "in-situ management of genetic resources". The results of the study are given in Table II. This analysis allowed us to identify certain priorities to be addressed by Malagazy institutes:

- necessity for a policy and a national strategy in genetic resources (in relation to the biodiversity strategy);

- need for an authority to coordinate and inform the various parties involved in genetic resources nationally.

Following this study, reflections on the policy and strategy in genetic resources followed in Madagascar. Some colleagues involved in our work contributed [22, $25]$. These reflections resulted in laws and rules of procedure $[13,19]$. The following stages of the management of the cycle of projects should wait for a definition of the national policy to be analyzed (Step 4: "Moving from Programming to Identification" and the next steps from [12]). The study has resulted in the need to consider the "genetic" dimension within the framework of a project of local management of renewable natural resources (2.2.). The assessment of some conservation projects in Madagascar has shown the absence of consideration of genetic resources or genetic diversity in their objectives and implementation steps [4].

\subsection{Overview of available knowledge on Prunus africana and Centella asiatica}

When searching for information on the two species under study, we extracted from the available literature relevant data on the biology and exploitation which may influence the genetic structure of the species. A summary of this work is presented below and summarized in Table III.

\subsubsection{Prunus africana (Hook. f) Kalkman}

$P$. africana is a long-lived evergreen tropical tree species belonging to the Rosaceae family [21]. It is found in sub-Saharan Africa (from Cameroon to 
Table I. Feasibility of benefit-sharing corresponding to the design of CBD.

\begin{tabular}{l|l|l}
\hline \multicolumn{2}{c}{ Criterion based on } \\
\hline $\begin{array}{l}\text { 1. Transaction } \\
\text { characteristics }\end{array}$ & $\begin{array}{l}\text { Asset specificity in the } \\
\text { transaction }\end{array}$ & $\begin{array}{l}\text { Do firms trade several resources or are they specialized in the resource involved in } \\
\text { our contract ? Can they obtain this resource from other countries? }\end{array}$ \\
\cline { 2 - 3 } & $\begin{array}{l}\text { Incertainty of the } \\
\text { transaction }\end{array}$ & Are market conditions stable or volatile? \\
\cline { 2 - 3 } & $\begin{array}{l}\text { Frequency of the } \\
\text { transaction }\end{array}$ & Does the transaction occur regularly? \\
\hline $\begin{array}{l}\text { 2. Relationship } \\
\text { existing } \\
\text { between actors }\end{array}$ & $\begin{array}{l}\text { Organization capacity } \\
\text { within parties }\end{array}$ & $\begin{array}{l}\text { Is there any association in the village? How many? What is the degree of involvement } \\
\text { of people? How is the harvesting activity organized? Is it an individual or a collective } \\
\text { activity? }\end{array}$ \\
\cline { 2 - 3 } & $\begin{array}{l}\text { Relationship existing } \\
\text { between parties }\end{array}$ & $\begin{array}{l}\text { What kind of relations exist between firms, research institutes, local community, } \\
\text { NGOs and other stakeholders in the contract? }\end{array}$ \\
\hline $\begin{array}{l}\text { 3. Scientific or technical characteristics } \\
\text { 4. Characteristics of the local context }\end{array}$ & $\begin{array}{l}\text { Are the parties able to apply technology transfer? Do they have the required struc- } \\
\text { tures? Are the actors able to apply conservation methods such as tree nurseries? }\end{array}$ \\
\hline
\end{tabular}


Table II. Checklist for final assessment and recommendations for support of "in situ management of genetic resources" (1998 work study).

\begin{tabular}{|c|c|}
\hline Theme & Comments \\
\hline $\begin{array}{l}\text { 1. Policy, legal and institu- } \\
\text { tional framework }\end{array}$ & $\begin{array}{l}\text { Relative absence of policy, and gap in the law on genetic resources. New favorable forest policy. Indistinctness of the mandates of } \\
\text { institutions, NGOs ... } \\
\text { Structures exist but problem of stake in work. Need for support for the elaboration of a national and regional policy (Commission of } \\
\text { Indian Ocean) of management of genetic resources. Need for a platform of coordination of parties engaged on aspects of information } \\
\text { and processes of decision on genetic resources. }\end{array}$ \\
\hline $\begin{array}{l}\text { 2. Conservation of ecosys- } \\
\text { tems and of biodiversity }\end{array}$ & $\begin{array}{l}\text { Major biological diversity, very strong rate of endemism. Not enough information about biological invasions. Importance of forests in } \\
\text { the society and the domestic Malagasy economy. A lot of uncontrolled exploitation and illicit export. Conflicts of interests between } \\
\text { conservation and development. Reflection to be deepened on aspects of genetic diversity and in-situ management of genetic resources. } \\
\text { Favorable national context }\end{array}$ \\
\hline $\begin{array}{l}\text { 3. Sustainable } \\
\text { management of } \\
\text { resources }\end{array}$ & $\begin{array}{l}\text { The value of genetic resources is unknown. Activity of craft transformation. No patent deposited in Madagascar on genetic resources. } \\
\text { Economic evaluation of profits to be realized on biodiversity. Conflicts between short-term subsistence and long-term management. } \\
\text { Consider genetic resources as strategic resources (Malagasy Office of Strategic Industries). Possible transfer of management of the } \\
\text { renewable natural resources towards the local populations (law Gélose), maybe also on phyto-genetic resources }\end{array}$ \\
\hline $\begin{array}{l}\text { 4. Creation of } \\
\text { resources }\end{array}$ & $\begin{array}{l}\text { Need for knowledge on the domestication of certain species. Ideas of the producing operators, not only harvesters. Connection } \\
\text { conservation in and ex-situ. A few fruitful attempts of plantations of local forested species, program of forestry farmer towards } \\
\text { genetic resources }\end{array}$ \\
\hline $\begin{array}{l}\text { 5. Harvesting, } \\
\text { processing, } \\
\text { marketing and } \\
\text { trading }\end{array}$ & $\begin{array}{l}\text { CITES species, competitor in use between certain resources, awareness of the non-viability of certain practices of exploitation. Major } \\
\text { changes in the fields of exploitation of possible biological and genetic resources. }\end{array}$ \\
\hline $\begin{array}{l}\text { 6. Certification of } \\
\text { management and } \\
\text { products }\end{array}$ & Everything remains to be considered and set up. \\
\hline 7. Education and training & Indispensable multidisciplinarity, strategy of increase and concentration of human resources to be strengthened \\
\hline $\begin{array}{l}\text { 8. Genetic } \\
\text { resource-related } \\
\text { research }\end{array}$ & $\begin{array}{l}\text { Madagascar: one of the best sites for the biological and socioeconomic conditions of the research. Opening on several disciplines, } \\
\text { strong institutional capacity and human resources. } \\
\text { Problems of financing and programming of the research, difficulty of availability of scientific information. }\end{array}$ \\
\hline $\begin{array}{l}\text { 9. Information and commu- } \\
\text { nication }\end{array}$ & $\begin{array}{l}\text { A failing sector (exchange, capacity of management, access and use, scattering). } \\
\text { Especially felt to be a key problem, between institutions, inside institutions, between scientists, users, administrations and policies. } \\
\text { Need to coordinate stakeholders. }\end{array}$ \\
\hline
\end{tabular}


Table III. Relevant information for assessing genetic diversity in Prunus africana and Centella asiatica.

\begin{tabular}{|c|c|c|}
\hline & Prunus africana (Hook. f.) Kalkman & Centella asiatica (L.) Urban \\
\hline Description & Long-lived evergreen tree species & Small perennial herb \\
\hline Family & Rosaceae & Apiaceae \\
\hline \multicolumn{3}{|c|}{ Taxonomy } \\
\hline $\begin{array}{l}\text { "Varieties" of } \\
\text { species }\end{array}$ & $\begin{array}{l}\text { Two forms are distinguished by harvesters } \\
\text { in Madagascar }\end{array}$ & $\begin{array}{l}\text { Several forms are distinguished } \\
\text { in Madagascar }\end{array}$ \\
\hline Vernacular names & $\begin{array}{l}\text { Many to few according to country and ethnic } \\
\text { division }\end{array}$ & Few in Madagascar \\
\hline \multicolumn{3}{|c|}{ Location } \\
\hline $\begin{array}{l}\text { Distribution area } \\
\text { Fragmented } \\
\text { distribution }\end{array}$ & $\begin{array}{l}\text { sub-Saharan Africa, Madagascar, Comoros } \\
\text { Yes }\end{array}$ & $\begin{array}{l}\text { Pantropical } \\
\text { Information not available }\end{array}$ \\
\hline Habitat & $\begin{array}{l}\text { Mid-late secondary species from } \\
\text { Afromontane forests }\end{array}$ & $\begin{array}{l}\text { Disturbed areas (dykes of rice fields, } \\
\text { shallows) }\end{array}$ \\
\hline Distribution type & Aggregated & Aggregated \\
\hline \multicolumn{3}{|c|}{ Reproductive biology } \\
\hline Reproductive biology & Sexual & Mainly clonal \\
\hline Sexual organs & Hermaphroditic & Hermaphroditic \\
\hline Mating system & Out-crossing & Information not available \\
\hline Phenology & Annual flowering and/or sporadic & Information not available \\
\hline Pollinization & Insects (and birds) & Information not available \\
\hline Dispersal & Birds and mammals & Information not available \\
\hline \multicolumn{3}{|c|}{ Uses } \\
\hline Use & Medicinal against prostate disorder & Medicinal and cosmetic to form scab \\
\hline $\begin{array}{l}\text { Part of the plant } \\
\text { utilized }\end{array}$ & Bark & Leaf \\
\hline Process & Bark extract & Molecule isolated \\
\hline Patents & Over 5 & Over 25 \\
\hline \multicolumn{3}{|c|}{ Utilization } \\
\hline Conservation status & Vulnerable (Appendix II of CITES) & Not threatened \\
\hline Threats & Overexploitation, deforestation & Irrelevant \\
\hline Harvesting practices & 1) Tree felling & 1) Plant removed \\
\hline & 2) Bark removal & 2) Cutting the leaves \\
\hline Is harvesting & Mainly not & Yes, apparently \\
\hline Sustainable? & & \\
\hline \multicolumn{3}{|c|}{ Suspected impact of practices on genetic diversity } \\
\hline $\begin{array}{l}\text { 1: exploited } \\
\text { individuals removed } \\
\text { 2: sustainable } \\
\text { harvesting }\end{array}$ & $\begin{array}{l}\text { Lost of genes and genotypes } \\
\text { None }\end{array}$ & $\begin{array}{l}\text { Disruptive selection in favor of less } \\
\text { productive clones }\end{array}$ \\
\hline
\end{tabular}

${ }^{4}$ Infra-specific divisions structuring genetic diversity (sub-species, ecotypes, varieties...)

Kenya and as far as South Africa) in Madagascar and in the Comoros Islands [9]. P. africana occurs in Afromontane forests up to $900 \mathrm{~m}$ (or $600 \mathrm{~m}$ in Madagascar). It is a mid-late secondary forest species, which grows best in forest gaps. It is a hermaphroditic species supposed to be mainly out-crossing, pollinated by insects (especially by bees) or perhaps birds and dispersed by birds and mammals. The species presents a sub-population structure over its range $[3,10]$.

$P$. africana is a multiple-use species with an international medicinal value. Bark extract is used to treat Benign Prostatic Hyperplasia (BPH). The market generated by this natural remedy has been evaluated at \$US 220 million. The species has been exploited for the international market since the seventies. It is now mainly exploited in Cameroon, Madagascar, Kenya, Equatorial Guinea 
and Tanzania $[8,18,23,28]$. At first, recommendations for the durable exploitation of the species were proposed but were only followed for a few years. They consisted of a partial de-barking of trees of $\mathrm{DBH}^{3}$ greater than $30 \mathrm{~cm}$, which did not cause much mortality and allowed a reexploitation of the same tree after 4 6 years [9]. It is now exploited essentially in a non-durable way [14] especially in Madagascar where the tree is cut down and totally barked [4,31]. Because of this overexploitation, in 1995, P. africana was included in the CITES appendix II, as a vulnerable species. ICRAF estimates that with the present harvesting practices, the species may become extinct within 5 to 10 years. This report prompted ICRAF to suggest a program to save this species [29,30].

\subsubsection{Centella asiatica (L.) Urban}

C. asiatica is a perennial herbaceous plant belonging to the Apiaceae family [32]. In Madagascar, one distinguishes an "abbreviata" form growing commonly in the high plateaux (native of tropical Asia, it became pantropical in the wet regions) [24]. One finds it in wet environments and in disturbed environments where it develops as plant carpets. It forms rampant stalk stolons and leaf rosettes. It reproduces by both vegetative and sexual means, but sexual reproduction is negligible [32].

In Madagascar, C. asiatica is widely used by traditional healers [5,7]. But international pharmaceutical and cosmetic industries also extract from the rosettes healing products such as Asiaticosid [6,23]. Madagascar is the main producing country because the rosettes of Malagasy $C$. asiatica have the highest content of the active product [27]. Exploitation does not seem to threaten the survival of the species [4].

\subsection{An economic organization detrimental to the preservation of biological resources}

Our work on the economic features of the exploitation of $P$. africana and of $C$. asiatica began in 1997 . We paid special attention to the analysis of the behavior of the various stakeholders involved, from the harvesters to the public agencies. Dysfunctions have been revealed, of which the recurrent cause seems to be a total lack of co-ordination of those involved, whose activity is mainly sporadic business dealings and who lack common knowledge of the global organization of the industry (Fig. 1).

The concurrent exercise of land and environment tenure, especially between local populations and the forestry administration, produces a no-rights situation resulting in a free access to the resources (Tab. IV and V). Each of those involved opportunely adopts, between law and custom, the most advantageous strategy, according to their own short-term interest. The results of research

${ }^{3}$ Diameter at Breast Height. 


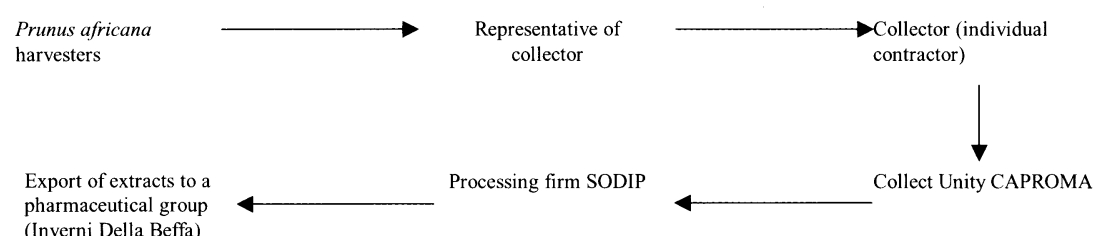

(a) Prunus africana commodity system since January 2000.

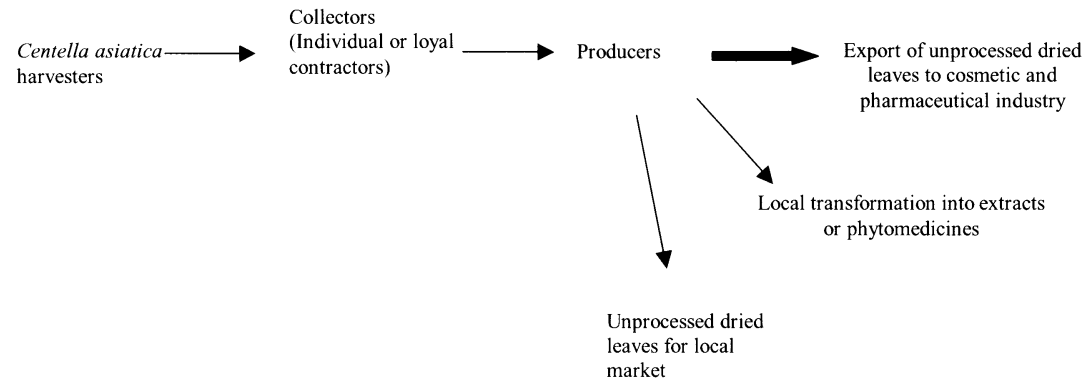

(b) Centella asiatica commodity system.

Figure 1. Prunus africana and Centella asiatica commodity systems.

on viable exploitation and management techniques are not disseminated, thus increasing the disparity in information available to those involved.

Thus, commercial tenure prevails on land and environment tenures and all viable management of the resources is inhibited. It is ensured only by private organizations and concerns all the resources taken in the ecosystems which are legally or customary owned. The only restriction possible is to place a species in the appendix 1 of CITES. The result of this procedure would be a total ban on commercializing the protected species. However, we lack the requisite information to place $P$. africana, which is nevertheless on the way to extinction, in the appendix 1. For $C$. asiatica, a common plant which reproduces vegetatively, there seems to be no overexploitation.

\subsection{Rapid appraisal of the impact of harvesting practices}

Table VI is an attempt to classify the effects of different harvesting practices according to the biology of the species. Following the work of Doligez [11], we have taken into consideration separate pollen and seed dispersal distances and the level of clumping. P. africana is considered in danger but little is known of the extent of the loss of genetic diversity. The fact that it regenerates better in gaps may be considered as a positive trait to be taken advantage 
Table IV. The distribution of norms implied by the exploitation of Prunus africana and of Centella asiatica on the east coast of Madagascar.

\begin{tabular}{|c|c|c|c|c|c|c|c|}
\hline $\begin{array}{l}\text { Scale implied } \\
\text { Origin of the } \\
\text { Claimed Right }\end{array}$ & Spatial categories & Ecosystem & Species & $\begin{array}{l}\text { Individualized } \\
\text { space }\end{array}$ & Population & $\begin{array}{l}\text { Individual of a } \\
\text { species }\end{array}$ & $\begin{array}{l}\text { Part or gene isolated from its } \\
\text { biological support }\end{array}$ \\
\hline Removal & & & & & $\begin{array}{l}\text { 9/ Forestry Right: Fetting of } \\
\text { taxes and commissions under } \\
\text { exploited resources } \\
\text { respectively by forestry } \\
\text { administration and by district }\end{array}$ & $\begin{array}{l}\text { 7/ Customary } \\
\text { Right: Farmers } \\
\text { individually } \\
\text { appropriate the } \\
\text { resources drawing } \\
\text { out from the } \\
\text { lineage's land }\end{array}$ & \\
\hline Domestication, & & & $\begin{array}{l}\text { 13/ Evironment Right: } \\
\text { settlement of sustainable } \\
\text { techniques of Prunus } \\
\text { exploitation }\end{array}$ & & & & \\
\hline Manufacture & & & & & & & $\begin{array}{l}10 / \text { Com merciai Right: Only a very } \\
\text { small part of the Prunus and Centella } \\
\text { production is used for the } \\
\text { manufacture of semi-processed or } \\
\text { finished products in Madagascar. } \\
12 / \text { Commercial Right: Foreign } \\
\text { patents covering processes and } \\
\text { products }\end{array}$ \\
\hline $\begin{array}{l}\text { Assignment by } \\
\text { customary } \\
\text { communities }\end{array}$ & & & & & $\begin{array}{l}\text { 6/ Customary Right: } \\
\text { Members of local community } \\
\text { draw out Prunus and Centella } \\
\text { from the land where all the } \\
\text { lineage's zebus graze }\end{array}$ & & \\
\hline Assignment by State & $\begin{array}{l}\text { registration of forests } \\
\text { established on } \\
\text { private and public } \\
\text { domain of State. }\end{array}$ & $\begin{array}{l}\text { Management of } \\
\text { Marests by forestry } \\
\text { administration } \\
\text { alone }\end{array}$ & & & $\begin{array}{l}\text { 4) Forestry Right: collect } \\
\text { and exploitation licenses } \\
\text { issued by the forestry } \\
\text { administration for a definite } \\
\text { geographical zone }\end{array}$ & & \\
\hline $\begin{array}{l}\text { Assingment by the } \\
\text { international } \\
\text { community }\end{array}$ & & & $\begin{array}{l}\text { 3/ Commercial Right: } \\
\text { Inscription of ppecies in } \\
\text { the annexes of } \\
\text { Washington convention } \\
\text { (CITES) }\end{array}$ & & & & \\
\hline Inheritance & & & & $\begin{array}{l}\text { 5/Customary } \\
\text { Right: Space } \\
\text { traditionally } \\
\text { reserved for } \\
\text { grazing of zebus. }\end{array}$ & & & \\
\hline Purchase & & & & & & & $\begin{array}{l}8 / \text { Commercial Right: Collectors } \\
\text { buy barks of Prunus and leaves of } \\
\text { Centella from the members of local } \\
\text { community. } \\
11 / \text { Commercial Right: Most of } \\
\text { resources are exported untreated }\end{array}$ \\
\hline
\end{tabular}

The numbers indicate the relation between identified rights (Tab. IV) and their enforcement in the context of tenure (Tab. V). 
Table V. Identification of tenures and their inscription in the patrimony of actors concerned by the exploitation of Prunus africana and Centella asiatica on the east coast of Madagascar.

\begin{tabular}{|c|c|c|c|c|c|}
\hline $\begin{array}{c}\text { Mode of } \\
\text { appropriation } \\
\text { Mode of } \\
\text { management }\end{array}$ & $\begin{array}{l}\text { Undifferentiated } \\
\text { tenure (thing) } \\
\text { access rights }\end{array}$ & $\begin{array}{c}\text { Priority tenure } \\
\text { (assets) } \\
\text { access and } \\
\text { extraction rights }\end{array}$ & $\begin{array}{l}\text { Specialized tenure } \\
\quad(\text { possession) } \\
\text { access, extraction and } \\
\text { management rights } \\
\end{array}$ & $\begin{array}{c}\text { Exclusive tenure } \\
\text { (ownership) } \\
\text { access, extraction, management } \\
\text { and exclusion rights } \\
\end{array}$ & $\begin{array}{c}\text { Exclusive and absolute } \\
\text { (property) } \\
\text { right of alienation }\end{array}$ \\
\hline $\begin{array}{l}\text { Public } \\
\text { (common } \\
\text { to all) }\end{array}$ & \multirow{4}{*}{\multicolumn{2}{|c|}{ In this case there no tenure of $t$}} & e following types & $\begin{array}{l}\text { 3/ Commercial tenure limiting access } \\
\text { restriction to resources which are on the } \\
\text { annexes of the CITES -> Public } \\
\text { administration }\end{array}$ & \\
\hline $\begin{array}{c}\text { External } \\
\text { (common to } \\
n \text { groups) }\end{array}$ & & & & $\begin{array}{l}\text { 13/ Environmental tenure based } \\
\text { on the technical and scientific knowledge } \\
\text { of experts }->\text { Scientific and Technical } \\
\text { organizations }\end{array}$ & $\begin{array}{l}8 ; 10 ; 11 / \text { Commercial tenure coming } \\
\text { from the owning of parts or genes isolated } \\
\text { from their biological support } \\
\text {-> private organizations } \\
\text { Commercial tenure coming from the } \\
\text { protection of intellectual property rights-> } \\
\text { foreign private organizations }\end{array}$ \\
\hline $\begin{array}{l}\text { Internal } \\
\text { (common to } \\
\text { one group) }\end{array}$ & & & & $\begin{array}{l}5 ; 6 ; 7 / \text { Land and forestry tenure } \\
\text { coming from local population customs } \\
\text { and defining the modalities of forestry } \\
\text { resources access }->\text { local community }\end{array}$ & \\
\hline $\begin{array}{c}\text { Private } \\
\text { (one person } \\
\text { special attribute) }\end{array}$ & & & & & $\begin{array}{l}\text { 1/ Land tenure coming from the usual } \\
\text { regime of registration.-> State Property } \\
\text { Department } \\
\text { 2; 4; 9/ Environmental tenure under } \\
\text { ecosystem and wild animal and plant } \\
\text { populations - > State (Forestry } \\
\text { administration) }\end{array}$ \\
\hline
\end{tabular}


Table VI. Impact of harvesting practices on genetic processes according to the biology of the species.

\begin{tabular}{llll}
\hline Harvesting practices & Non-reproductive parts* & Reproductive parts ** & Whole plant \\
Biological traits & & \\
\hline $\begin{array}{l}\text { Rare endemic } \\
\text { Rare low density }\end{array}$ & Direct or indirect selection & $\begin{array}{l}\text { Drift } \\
\text { Drift, mating system }\end{array}$ & $\begin{array}{l}\text { Drift, mating } \\
\text { system }\end{array}$ \\
$\begin{array}{l}\text { Clumped } \\
\begin{array}{l}\text { Late age of first flowering } \\
\text { (long generation time) }\end{array}\end{array}$ & $\begin{array}{l}\text { Drift } \\
\text { Short distance of pollination } \\
\begin{array}{l}\text { Short distance of seed } \\
\text { dissemination }\end{array}\end{array}$ & Mating system & Mating system \\
$\begin{array}{l}\text { Ecological requirement of } \\
\text { shade for seedling } \\
\text { establishment }\end{array}$ & Mating system & Mating system & Mating system \\
$\begin{array}{l}\text { Possible vegetative } \\
\text { reproduction }\end{array}$ & Migration & Migration \\
\hline
\end{tabular}

* assuming that the technique of harvesting does not reduce the reproductive potential of the plant.

** timing of the harvesting is particularly important in this case as early harvesting could prevent reproduction.

of in rehabilitation schemes. C. asiatica reproduces mainly vegetatively and therefore harvesting of the leaves does not threaten the species' survival, but the modification of the selection pressure by intensive harvesting could strongly modify the genetic diversity as some clones may spread more extensively. Lack of basic biological data limits the predictions which can be made. Modeling will help to assess which biological traits are most likely to have a strong impact on the loss of genetic resources according to harvesting practices.

\subsection{Influence of types of economic fields on the possible sharing of benefits}

\subsubsection{Present state of benefit-sharing}

For several reasons, the present state of benefit-sharing does not really correspond to the recommendations of the Convention on Biological Diversity (Tab. VII). Harvesters are paid only for their work and there is no payment related to the plant value itself. They receive about $3 \%$ of the export value of the resource. Moreover, as exploitation permits are issued at a regional level of administration, local villagers have no control over the exploitation of their resources [20]. No fees for possible rights on traditional knowledge are distributed either. And finally, the absence of scientific collaboration or technology transfer is flagrant in the case of $C$. asiatica in spite of the existing potential. 
Table VII. Present sharing of benefits in the commodity systems of Prunus africana and Centella asiatica in Madagascar.

\begin{tabular}{|c|c|c|c|}
\hline Beneficiaries & Benefits & Prunus africana & Centella asiatica \\
\hline Harvester & Wage due to the harvest & $\begin{array}{l}500 \mathrm{fmg} / \mathrm{kg} \text { fresh } \\
1500 \mathrm{fmg} / \mathrm{kg} \text { dried }\end{array}$ & $\begin{array}{l}\text { Price IMRA: } 600 \text { to } \\
700 \mathrm{fmg} / \mathrm{kg} \text { fresh according } \\
\text { to quality; } 6000 \mathrm{fmg} / \mathrm{kg} \\
\text { dried. }\end{array}$ \\
\hline Collector & $\begin{array}{l}\text { Commercial margin } \\
=\text { selling price to exploiter } \\
\text { - Purchase price to harvester } \\
\text { - Taxes } \\
\text { - Transportation costs }\end{array}$ & $\begin{array}{l}\text { Selling price to Sodip: } \\
\text { between } 2250 \text { and } \\
3000 \mathrm{fmg} / \mathrm{kg} \text { dried } \\
\text { according to quality }\end{array}$ & $\begin{array}{l}\text { Selling price to the } \\
\text { exploiter: } 8000 \mathrm{fmg} / \mathrm{kg} \\
\text { dried* }\end{array}$ \\
\hline Exploiter & $\begin{array}{l}\text { Profits from processing } \\
\text { and/or export }\end{array}$ & $\begin{array}{l}\text { Export price (FOB): } \\
19000 \mathrm{fmg} / \mathrm{kg}^{*}\end{array}$ & $\begin{array}{l}\text { Export price (FOB): } \\
21000 \mathrm{fmg} / \mathrm{kg}^{*}\end{array}$ \\
\hline \multirow[t]{2}{*}{ Government } & $\begin{array}{l}\text { Taxes collected by the } \\
\text { District } \\
\text { Taxes collected by the Forest } \\
\text { Ministry on collecting activity }\end{array}$ & $\begin{array}{l}\mathrm{fmg} / \mathrm{kg} \text { dried }+ \text { nursery } \\
\text { obligation } \\
105 \mathrm{fmg} / \mathrm{kg} \text { dried }\end{array}$ & $\begin{array}{l}55 \mathrm{fmg} / \mathrm{kg}^{*} \text { dried }+ \text { in kind } \\
\text { payments } 50 \\
140 * \mathrm{fmg} / \mathrm{kg} \text { dried }\end{array}$ \\
\hline & $\begin{array}{l}\text { Taxes collected by the Forest } \\
\text { Ministry on export }\end{array}$ & $\begin{array}{l}\text { Semi-processed products: } \\
1.5 \% \text { of export FOB value }\end{array}$ & $\begin{array}{l}\text { Unprocessed products: } 4 \% \\
\text { of export FOB value }\end{array}$ \\
\hline Importer & $\begin{array}{l}\text { Profits from pharmaceutical } \\
\text { production }\end{array}$ & & \\
\hline
\end{tabular}

(*) 1998 figures; the others were updated in 2000.

\subsubsection{Prunus africana: a scenario ensuring more equitable benefit-sharing with the goal of a sustainable exploitation of the resource}

The scenario for this species is based on the decentralization of rights over these resources from the state to local communities. The study showed a lack of management of this resource by the state, mainly because of the lack of information on resource locations and practices of exploitation. Unlike those of C. asiatica, $P$. africana resources are threatened (appendix 2 CITES) and are partially processed locally. The overexploitation and the economic value of $P$. africana lead us to suggest a bilateral contract between a local processing firm and local rural communities. This contract could be based on the possibility of legal transfer of management of natural resources from the State to local communities ("Gélose" Law). It would be established between a rural community and a local firm processing the resources. The contract would aim to link $P$. africana harvesters directly to this firm to control harvesting conditions better. The challenge is to restore the balance between economic profitability, sharing of benefits between those involved and sustainable management of the resources. The actual harvesting practices will probably have to be drastically modified. 


\subsubsection{Centella asiatica: a scenario ensuring more equitable benefit-sharing thanks to technology transfer}

Based on the data collected, we elaborated a scenario where access to $C$. asiatica is granted to foreign companies for external trade and compensated by technology transfer to local processing. The intensity of harvesting of $C$. asiatica does not seem to put the resources at risk for the time being. C. asiatica is now exported unprocessed despite existing potential for local processing which would provide a greater return for Malagasy stakeholders. The future legal possibility of patenting pharmaceutical products in Madagascar offers opportunities in the development of phytomedicinal products. The compensation for accessing the resource can be established through a contract between a parastatal firm (involved in export, production and research activities) and the importer (pharmaceutical company) to organize transfer of technology regarding processes in order to develop a local phytomedical industry. In the development of this contract, the power of negotiation would be held mainly by the pharmaceutical company.

Both these contracts are possibilities for adapting the present exploitation of biological resources to the CBD. Later, an evaluation would be needed (4.3.).

\section{DISCUSSION}

\subsection{What is useful biological information?}

The results of the bibliographical search showed that the available information on Centella asiatica and on Prunus africana was very scarce and scattered. The absence of documentation of the origin of the information leads to problems of interpretation and to questions about the validity of the supplied information. This also leads to a situation in which the initial information is multiplied and without indication of origin and can be interpreted as a confirmation of the initial information while it is only a rehearsal. However, by completing the available biological information with field work and surveys, we were able to propose a first diagnosis including legal, economic and technical characteristics of management of these two species. This diagnosis allowed us to elaborate scenarios and to propose measures which, even if they are not optimal enable us to make recommendations to the various stakeholders (State, NGOs, legislator...). Nevertheless, in most cases a more refined diagnosis will have to be made. A systematic approach should be developed to identify which information is useful for management purposes and to follow up the impact of harvesting practices on genetic diversity. 


\subsection{Elaboration of an institutional environment favoring the inter- dependency of stakeholders involved in a viable management of biodiversity}

By using the matrix (Tab. IV) we can visualize the interdependency of the organization of the actors who are included in the case-by-case establishment of juridical production in accordance with a coherent global system. This coherence is based on a pertinent distinction of right's objects (which ecological order make interdependent) and on a widening of right's sources (a possibility which is given by the patrimonial negotiations in the frame of the new laws).

The matrix of tenure (Tab. V) allows us to encompass the diversity of juridical regimes arising from the introduction of new categories as a result of compilation of traditional and civil rights. We can propose another scenario [1]: land tenure, on which depends access to the resources, is held by the local community and guaranteed by the State. The environmental tenure which makes it possible to supervise the management of natural renewable resources is shared between the forestry administration, the holder of technical and theoretical knowledge, and the local community, the keeper of empirical knowledge. At least the trading tenure on which depend the way of circulating resources is based on the expression of patrimonial rights which come from the respect of procedures and norms previously evoked.

It is likely that this type of scenario will be soon applied in Madagascar. But its efficiency depends not only on the viability of the juridical framework in which it will be integrated. Its establishment is a necessary but not sufficient condition. The viable management of biological diversity and the real involvement of the actors also depends on an institutional arrangement negotiated by the stakeholders, including the fair and equitable sharing of advantages.

\subsection{Analyzing economic fields to propose benefit-sharing contracts}

\subsubsection{Approach based on feasibility}

This approach (Tab. I) considers ecological, economic and social aspects of the resource which can influence the achievement of benefit-sharing. To be able to give a realistic assessment, collaboration with other disciplines, such as law or biology, is needed. For example, relationships involved in the contract must be consistent with the context expressed by national legislation. In terms of biology, it is also necessary to check the consistency between the type of exploitation implied by the contract and the ecological capacity of the resource. The panel could then be improved by evaluation of economic and ecological indicators. Furthermore, it would be interesting to apply this approach to bioprospection contracts or agricultural resources. 


\subsubsection{Approach based on negotiating power}

This approach (Tab. VIII) considers the influence of interests and strategies managed by the actors involved in exploitation of the resource. Although this dimension appears essential for studying the conditions of benefit-sharing, the approach was inapplicable. It should be improved by analysis of the negotiation and conciliation process.

\section{CONCLUSIONS AND PERSPECTIVES}

\subsection{Conclusions}

The methods and tools developed, adapted or used in this study are not specific to the conditions in Madagascar nor to the studied natural resources. The same frame could be used in all the cases where a contractual management of natural and renewable resources is envisaged. In these situations, various actors are obliged to share information to build a new and accepted social order corresponding to the agro-ecological and socio-economic constraints. We have addressed these questions through approaches in which the scientific disciplines complement each other in the diagnosis of the situation and in the management decision-making processes. The multidisciplinary method which we have implemented in this study also allows us to identify new questions for each discipline. In the legal domain, our work has shown that the in-situ management of genetic resources cannot be settled only with rights of intellectual property. It should consider numerous legal areas (property, access and exchange rights). The main difficulty lies in establishing coherence between a plurality of objects of rights and subjects of rights in a context associating legal and customary rights. By studying existing economic fields, we have shown that the contractual relations allowing a sharing of the advantages stemming from the exploitation of the genetic resources should often integrate more than two parties. Questions of multilateral contracts have been relatively little studied. In the case of Madagascar the State remains a major force. Its role is not to directly manage the resource but to enforce the agreements. This role is too often ignored in the literature on CBD implementation. The process of management transfer is on its way, and as was clearly stressed in the main guidelines for biodiversity strategy the state has to change roles and responsibilities.

Another question remains to be dealt with by economists: what is a fair and equitable sharing and how can it be implemented? The work-handling impact of practices on genetic diversity underlined the poverty of the relevant information for managing the species under study, in spite of their economic importance. To be able to manage in-situ the genetic resources of numerous species seems to be unrealistic unless we can identify large categories of species according to their main biological traits and the way they are harvested. Nevertheless, 
Table VIII. Influence of negotiation power in the achievement of benefit-sharing.

\begin{tabular}{l|l|l}
\hline \multicolumn{2}{c}{ Factors of power } & \multicolumn{2}{c}{ Ways of evaluation } \\
\hline \multirow{2}{*}{ 1. Coercion power } & National legislation & $\begin{array}{l}\text { What is the legislation linked to the achievement of fair benefit-sharing? Is } \\
\text { there any mechanism of enforcement? What can force parties to enter into } \\
\text { such a contract? }\end{array}$ \\
\cline { 2 - 2 } $\begin{array}{l}\text { Convention and international } \\
\text { agreements } \\
\text { (CBD + TRIPS) }\end{array}$ & Lobbying \\
\cline { 2 - 3 } $\begin{array}{l}\text { 2. Negotiating } \\
\text { power }\end{array}$ & $\begin{array}{l}\text { Property rights distribution (in- } \\
\text { tellectual property on innovation, } \\
\text { resource or knowledge, access } \\
\text { rights...) }\end{array}$ & $\begin{array}{l}\text { For each stakeholder (firm, institution, local community...), what are the op- } \\
\text { portunities opened by the rights? }\end{array}$ \\
\cline { 2 - 3 } $\begin{array}{l}\text { Information asymmetries } \\
\text { on market conditions }\end{array}$ & $\begin{array}{l}\text { Does each actor know the final value of products made from collected re- } \\
\text { sources? }\end{array}$ \\
\cline { 2 - 3 } $\begin{array}{l}\text { Information asymmetries } \\
\text { on legislation }\end{array}$ & $\begin{array}{l}\text { Does each actor own the same information about legislation and rights he can } \\
\text { claim? }\end{array}$ \\
\cline { 2 - 3 } & $\begin{array}{l}\text { Degree of competition } \\
\text { What are the characteristics of the resource market? (number of buyers / } \\
\text { sellers) Is there any competition between countries-source? between local } \\
\text { harvesters? }\end{array}$ \\
\cline { 2 - 3 } & Are financial and technical assets, owned by each party, well-balanced? \\
\cline { 2 - 2 }
\end{tabular}


it seems to us that there is a risk of oversophistication as the tools may be unusable in a context of low technical and financial means.

\subsection{Perspectives}

This work contributes to the debate on the scientific knowledge and on the necessary and sufficient information needed for managing genetic resources insitu. It seems to us that sharing this knowledge and this information should be central in accommodating the multiple interests of the stakeholders [2].

The work presented here on $C$. asiatica and $P$. africana in Madagascar represents two biological cases and two different commodity systems in the framework of a given set of laws. It is not realistic to develop such a detailed study for a very large number of species in different legislative frameworks. We would therefore pursue our work with the help of modeling, in an approach integrating the biological traits of a given species, the stakeholders and especially the harvesting practices and the legislative background. We would like to model the interactions between the behaviors of the actors and the evolution of the resources in a given legislative environment. According to the presence or absence of rival normative systems, according to the consistency of juridical, biological and economic categories, according to how rights and obligations are distributed between the actors, different scenarios of $i n$-situ management of genetic resources can be elaborated. From simulations computed with the model we could evaluate their viability both ecologically and economically. According to the aims of the CBD, and in order to share information and knowledge, such a tool has to be integrated into the decision-making processes.

We are now developing a training tool for the management of genetic resources in the form of role play assisted by multi-agent simulations applied to the Malagasy context. The methods and tools used in our study feed some of the modeling integrated into the game. When this product is finished, it will be available for administrators of genetic resources and also for the local communities which could ask for the transfer of management of the genetic resources.

The contractual logic promoted by the CBD seems rather difficult to apply without accompanying procedures and an adequate institutional environment. This should be considered by the international community as well as by all the stakeholders concerned by in-situ management of genetic resources. Local, national and international contracts must take into account factors arising from very different domains. The feasibility of contracts and the management scenario imposes joint ecological, genetic, technical, economic and political considerations. The changes, sometimes considered as necessities, are considerable and call for a review of practice and mentalities. This is particularly true in the case of the transfer of technology. "Technology transfer objectively means the transfer of a whole structure and a social context. [...] There is no neutral 
technology. Technology is always associated with a global structure determined by a global vision of the world and of man." [26]

\section{ACKNOWLEDGEMENTS}

The authors are grateful to Mamy Razafindrabe (†), Huges Andriamanbavola, Jean-Marc Garreau, Benoit Delaite, Erick Rakotomavo, Miora Andoniaina Rasoamampianina and Marie-Angèle Hermitte for their contribution or their help, and to the inhabitants of the districts of Andapa, Didy and Moramanga for taking part in interviews. They are also grateful to the following institutes (DGEF, SNGF, ONE, OMAPI, FOFIFA, WWF, Miray, CNARP, IMRA) for their support.

This work was funded by a grant from the French Bureau des ressources génétiques (BRG).

\section{REFERENCES}

[1] Aubert S., Gestion patrimoniale et viabilité des politiques forestières à Madagascar, vers le droit à l'environnement ? Thèse pour le doctorat en Droit, Université Paris I Panthéon Sorbonne, Paris, 1999.

[2] Babin D., Bertrand A., Weber J., Antona M., Patrimonial mediation and management subsidiarity: managing pluralism for sustainable forestry and rural development, in : Pluralism and sustainable forestry and rural development, Rome, Italy, FAO-IUFRO-CIRAD, Rome, 1999, pp. 277-303.

[3] Barker N. P., Cunningham A. B., Morrow C., Harley E.H., A preliminary investigation into the use of RAPD to assess the genetic diversity of a threatened African tree species: Prunus africana, Strelitzia 1 (1994) 221-230.

[4] Béchaux E., Vers une gestion in-situ des ressources génétiques végétales à Madagascar, Mémoire d'ingénieur, ENESAD-CIRAD, Dijon, 1999.

[5] Boiteau P., Bulletin de la Société du Parc Botanique et Zoologique de Tananarive: $8^{\text {ème }}$ rapport, 1944.

[6] Boiteau P., Ratsimamanga A. R., L'asiaticoside extrait de Centella asiatica et ses emplois thérapeutiques dans la cicatrisation des plaies expérimentales et rebelles (lèpre, tuberculose cutanée et lupus), Thérapie (11) 1 (1956) 125-149.

[7] Boiteau P., Boiteau M., Allorge-Boiteau L., in: Dictionnaire des noms malgaches de végétaux, Alzieu C. (ed.), Grenoble, 1999.

[8] Cunningham A. B., An Africa-wide overview of medicinal plant harvesting, conservation and health care, Medicinal Plants for Conservation and health care, Non Wood Forest Products 11, FAO, Rome, 1995.

[9] Cunningham A. B., Mbenkum F. T., Sustainability of harvesting Prunus africana bark in Cameroon. A medicinal plant in international trade, People and Plants Working Paper $\mathrm{n}^{\circ}$ 2, UNESCO, 28, Paris, 1993.

[10] Dawson I. K., Powell W., Genetic variation in the Afromontane tree Prunus africana, an endangered medicinal species, Mol. Ecol. (8) 1 (1999) 151-156. 
[11] Doligez A., Baril C., Joly H.I., Spatial genetic structure and diversity within forest tree populations, Genet. Select. Evol., 30, suppl. 1 (1998) 167s-180s.

[12] European Communities-Commission, Forest in Sustainable Development, Tools for Project Cycle Management, Office for Official Publications of the EC, Luxembourg, 1997.

[13] Hermitte M.-A., Diversité biologique et propriété intellectuelle à Madagascar, ONE, Antananarivo, 2000.

[14] Laird S. A., Lisinge E., Benefit-Sharing Case studies: Aristocladus korupensis and Prunus africana, Submission by the UNEP, UNEP/CBD/COP/4/inf.25: 49, 1998.

[15] Le Roy E., Le jeu des lois, Une anthropologie "dynamique" du droit, Maison des Sciences de l'Homme. Paris, 1999.

[16] Mounolou J.C., Fridlansky F., Biosciences and bioeducation in administrative decision-making, Biol. Int. 39 (2000) 22-32.

[17] Namkoong, G., Buyle T., Gregorius H.R., Joly H., Savolainen O., Ratman W., Young A., Testing criteria and indicators for assessing the sustainability of forest management: genetic criteria and indicators, CIFOR, Jakarta, 1996.

[18] Ndibi B.-P., Kay E.J., The regulatory framework for the exploitation of medicinal plants in Cameroon: The case of Prunus africana on Mount Cameroon, Biodiv. Conserv. (6) 10 (1997) 1409-1412.

[19] Office National pour l'Environnement, Stratégie de partage équitable des bénéfices découlant de l'exploitation des ressources biologiques, ONE, Antananarivo, 2000.

[20] Péchard G., Regard économique sur les règles du jeu gouvernant le partage des avantages tirés de l'exploitation de la biodiversité. Illustration par deux études de cas réalisés à Madagascar sur des ressources biologiques d'intérêt pharmaceutique, DEA de Sciences Économiques (Économie du développement agricole, agro-alimentaire et rural). ENSAM, Université de Montpellier I, CIRAD, Montpellier, 2000.

[21] Pousset J.L., Plantes médicinales africaines, Ellipses et ACCT, Paris, 1992.

[22] Ramamonjisoa L., Atelier national sur les ressources phytogénétiques forestières, Silo National des Graines ForestièresAntananarivo, 1999.

[23] Rasoanaivo P., Rain Forests of Madagascar: Sources of Industrial and medicinal plants, Ambio (19) 8 (1990) 421-424.

[24] Rasoanaivo P., Plantes médicinales et aromatiques à valeur économique à Madagascar, Les cahiers du CITE (Nouv. ser. 4), 1996.

[25] Ravelomanantsoa L., Andriantsilavo F., Raharimaniraka L., Étude de la réglementation malgache en vigueur relative à l'accès, la collecte, et l'exportation des ressources génétiques, au droit de la propriété intellectuelle et à la protection des connaissances traditionnelles, ONE, Antananarivo, 1999.

[26] Razafindrabe M., Logiques lignagère, capitaliste et socialiste chez le paysan malgache, thèse d'Anthropologie économique, Paris VII, Paris, 1989.

[27] Rouillard-Guellec F., Robin J.-R., Rakoto-Ratsimamanga A., Ratsimamanga S., Rasaoanaivo P., Étude comparative de Centella asiatica d'origine malgache et d'origine indienne, Acta botanica Gallica (144) 4 (1997) 489-493.

[28] Sunderland T.C.H., Tanyi Tako C., The exploitation of Prunus africana on the island of Bioko, Equatorial Guinea, Report for the People and Plants Initiative, WWF-Germany and the IUCN/SSC Medicinal Plant Specialist Group, 1999. 
[29] Tchoundjeu Z., Avana M. L., Leakey R.R.B., Simons A., Asasah E., Duguma B., Bell J.M., Vegetative propagation of Prunus africana: effects of rooting medium, auxin concentrations and leaf area, in prep.

[30] Tchoundjeu Z., Duguma B., Tiencheu M.-L., Ngo-Mpeck M.-L., The domestication of indigenous agroforestry trees: ICRAF's strategy in the humid tropics of west and central Africa, in : Sunderland T. C. H. , Clark L. E., Vantomme P. (eds.), Current research issues and prospects for conservation and development, FAO, Rome, 1999.

[31] Walter S., Rakotonirina J.-C.R., L'exploitation de Prunus africanum à Madagascar, PCDI Zahamena et DEF, Antananarivo,1995.

[32] Wankhar B., Tripathi R. S., Population Dynamics of Centella asiatica (Linn.) Urb., A clonal herbaceous perennial in "Jhum" Fallows, Trop. Ecol. (34) 1 (1993) 35-43. 